\title{
Predicting Word Reading and Word Writing of Kindergarteners with Phonology, Orthography, Morpho-semantics
}

\author{
Sangeun Won ${ }^{\mathrm{a}}$, Hyoeun Won ${ }^{\mathrm{b}}$, Woojeong Jang ${ }^{\mathrm{b}}$, Joungmin Lee ${ }^{\mathrm{b}}$, Soyeong Pae \\ ${ }^{a}$ Department of Speech Pathology, Graduate School of Health Sciences, Hallym University, Chuncheon, Korea \\ ${ }^{b}$ Department of Speech-Language Pathology and Audiology, Graduate School of Hallym University, Chuncheon, Korea \\ 'Division of Speech Pathology and Audiology, Hallym University, Chuncheon, Korea
}

Correspondence: Soyeong Pae, $\mathrm{PhD}$ Division of Speech Pathology and Audiology, Hallym University, 1 Hallimdaehak-gil, Chuncheon 24252, Korea

Tel: $+82-33-248-2214$

Fax: +82-33-256-3420

E-mail: spae@hallym.ac.kr

Received: July 5, 2020

Revised: July 25, 2020

Accepted: July 25, 2020
Objectives: It has been known that Korean preschoolers are actively engaged in reading and writing development. The purpose of this study was to examine the extent of Korean children's word reading and word writing abilities by phonological, orthographic, and morpho-semantic abilities. Methods: Seventy 5- to 6-year-old children were participants of this study and their average of IQ score was 100. Each child read and wrote 14 two-syllable words and 14 two-syllable nonsense words and the accuracy was scored at grapheme level. Phonological processing abilities were measured by phonological awareness (PA), rapid automized naming (RAN), phonological memory (PM); whereas letter knowledge (LK) and copying skills were measured for orthographic abilities, and morphological awareness (MA), vocabulary, story grammar recalling for morpho-semantic abilities. Multiple regression analyses were performed with SPSS 23.0. Results: LK, RAN, PM, and MA explained 57.2 percent of word reading while LK, RAN, PM, and copying explained 65.1 percent of nonsense word reading. LK, copying, MA explained 66.7 percent of word writing while copying, PA, and LK explained 59.1 percent of nonsense word writing. Conclusion: Given that RAN and PM explained word and nonsense word reading, and PA explained nonsense word writing, phonological processing abilities seemed to be involved in early literacy actively. Korean children seemed to be in partial to full alphabetic stage before formal elementary education. Most interestingly, the dual-route word reading model differentiating lexical and non-lexical route could be applied to Korean children's early reading development. Further studies are needed to explore early identification of developmental dyslexia from the kindergarten level.

Keywords: Korean kindergarteners' word reading and word writing, Phonological processing skills, Orthographic knowledge and copying, Morphological awareness
만 5-6세 아동은 읽기 전 단계와 음성음운 단계에 속한다(Chall, 1996). 읽기 발달의 시작 단계에서 성인과 인쇄물을 통한 상호작용 을 통해 인쇄물에 대한 지식을 쌓는 문해 사회화가 이루어지면 글 자의 이름을 말하는 글자 인식과 친숙한 단어를 보고 통으로 읽어 내는 통글자 읽기가 시작된다. 그 이후 자소와 음소의 대응 규칙과 글자 체계에 대한 지식을 익히는 음성음운단계에 들어서는 것이다. 낱말 수준의 읽기와 쓰기는 비슷한 인지과정을 거치며 발달 초기
에는 마치 동전의 양면과 같다(Ehri, 2000), 성공적인 낱말읽기를 위해서는 제시된 낱말에서 낱말을 구성하는 자소들을 보고, 각 자 소에 대응되는 음소를 연결하여 읽는 능력이 필요하다. 성공적인 낱말 쓰기를 위해서는 쓰고자 하는 낱말의 음운 표상을 떠올리고 각 음소와 대응되는 자소를 철자법과 순서에 맞게 조합하여 쓰는 능력이 필요하다.

현재 국가 수준에서 공식적인 한글 교육은 초등학교 1학년부터 
시작되지만, 대부분의 경우 유치원기부터 이미 읽기 교육이 가정, 유치원, 어린이집에서 이루어지고 있다(Park \& Park, 2014). 2013년 에 만 3-5세 아동을 지도하는 유치원과 어린이집 교사들을 대상으 로 유아에 대한 읽기 지도 수준을 조사한 결과, 교사들은 주로 '다 섯 개 이상의 단어를 읽을 수 있도록 지도한다. 혹은 '간단한 문장을 읽을 수 있도록 지도한다.로 보고하였다(Park, Kim, \& Park, 2013). 이러한 지도 수준은 누리과정(Ministry of Health and Welfare, 2019) 내 의사소통 영역에 제시된 읽기 및 쓰기 관련 목표인 '말과 글의 관계에 관심을 가진다., '자신의 생각을 글자와 비슷한 형태로 표현한다.와는 차이가 있는 것으로 보인다.

유치원기에 읽기 및 쓰기 교육이 이루어짐에 따라, 유치원 아동 의 초기 읽기 및 쓰기 발달은 이미 이루어지고 있다. 유치원 아동의 읽기, 쓰기 능력을 살펴본 선행 연구에서 자소와 음소가 일치된 의 미 낱말은 유치원 아동들도 $97 \%$ 의 정확도로 해독할 수 있었다 (Kim \& Pae, 2007). 형식적인 국어 교육이 시작되기 전인 3월 말의 초등학교 1학년 아동의 단어 해독 능력을 살펴본 결과에서도 자소 와 음소가 일치하는 의미 낱말을 $83 \%$ 이상의 정확도로 해독할 수 있었다(Jeong, 2014). 또한, 만 5 세 아동을 대상으로 한 철자 발달에 대한 종단연구 결과 기본 모음(, , - , , . , T, 一, I)과 기본 초성 ( ᄀ, ᄂ, ᄃ, ㄹ, ㅁ, ㅂ, ㅅ, ㅈ)은 초등학교 입학 전까지 발달이 완성 되는 것으로 나타났다(Yang, 2009). 일반 초등 1-2학년에는 자소와 음소가 일치하는 철자 쓰기는 이미 완성단계에 도달한 것으로 나 타났다(Shin, 2017; Song, Shin, \& Pae, 2016).

이중경로모형(Dual Route Cascaded Model)에서는 낱말의 친숙 도와 의미 유무에 따라서 읽기 과정을 처리하는 경로에 차이가 있 다고 하였다(Coltheart, Rastle, Perry, Langdon, \& Ziegler, 2001). 의 미 낱말 및 친숙한 낱말을 읽을 때는 주로 어휘 경로를 거치며 글자, 소리, 의미 정보가 표상되어 있는 어휘집을 사용한다. 반면 무의미 낱말 및 비친숙한 낱말을 읽을 때는 비어휘 경로를 거쳐 자소-음소 대응규칙에 의존하여 읽는다. 따라서 잘 아는 낱말을 읽을 때와 처 음 접하는 낱말을 읽을 때 수행력과 속도는 다르게 나타난다. 국내 연구에서 음운해독 단계 아동이 의미 낱말읽기에 비해 무의미 낱말 읽기의 수행력이 낮게 나타나(Kim \& Pae, 2007; Kim \& Pae, 2011; Yoon, Kim, \& Pae, 2011) 무의미 낱말 읽기를 할 때는 비어휘 경로 를 사용하는 것으로 보인다.

낱말을 읽고 쓰는 것은 낱말의 수준뿐만 아니라 음운, 철자, 형태 및 의미력과도 밀접한 관련이 있다(Bahr, Silliman, Berninger, \& Dow, 2012; Berninger et al., 2006; Berninger, Abbott, Nagy, \& Carlisle, 2010; Seidenberg, 2005). 또한 낱말 쓰기에 대한 3중 단어 구성 이론(triple word-form theory)에서는 쓰기 발달 초기에 영향을 미
치는 요인을 음운적, 철자적, 형태적 측면 3가지로 설명했다(Berninger et al., 2006). Choi와 Lee (2010)는 음운처리 능력, 자모음 지 식, 어휘력이 국내 만 4-5세 유아의 초기 문해 교육에서 중요한 변인 임을 확인하였고, 단어 쓰기에 대해서 쓰기에 적용되는 기본 요소 들을 이해하는 유아는 자소와 음소 관계뿐만 아니라 음운인식능 력을 갖고 있으며 이러한 유아들이 개별 철자의 기능을 이해하고 있다고 하였다. 이렇듯 발달 시기에 따라서 세 가지 요인 중 특정 요 인이 급격히 발달하거나 비교적 천천히 발달할 수는 있지만, 어떠 한 순서에 따라 순차적으로 발달하는 것이 아니라 공동으로 함께 발달함으로써 문해력을 형성한다.

음운처리력 중 말소리를 인식하고 조작하는 능력인 음운인식력 은 학령전기 아동의 읽기 능력과 강한 상관성이 있으며 읽기 능력 을 예측하는 변인으로 나타났다(Cho, McBride-Chang, \& Park, 2008; Kim \& Petscher, 2011; Kim, Al Otaiba, Puranik, Folsom, \& Gruelich, 2014). 또한 음운인식력은 쓰기 능력에 대해서도 고유한 설명력이 있는 것으로 나타났다(Kim \& Petscher, 2011; Kim et al, 2014; Puranik, Lonigan, \& Kim, 2011). 문자, 숫자 혹은 그림과 같 은 상징을 보고 장기기억에 저장된 정보에 접근하여 인출해내는 능 력인 빠른이름대기 능력의 수행력이 높을수록 더 정확하고 유창한 낱말 읽기를 하는 것으로 나타났으나(Cho et al., 2008; Kim \& Petscher, 2011; Park, Cho, \& Yu, 2013), 낱말 쓰기 능력에 대해서는 유 의미한 설명력을 갖지 않는 것으로 나타났다(Park, S. G. et al., 2013). 음운기억력은 음운인식, 빠른이름대기와 함께 초기 읽기 발달에 영향을 미치고(Kim \& Kim, 2009), 낱말 읽기 및 낱말 쓰기와작업 기억이 직접적인 관계가 있다는 결과를 제시한 선행연구가 있다 (Kim, 2017; Kim \& Schatschneider, 2017). 반면 Wagner 등(1997) 은 음운기억력이 읽기와 유의한 상관을 보이나, 독립적으로 초기 읽기 능력을 예측하지 못한다고 하였으며, Kim, Yoo와 Kim (2010) 는 유치원 아동의 작업기억과 단기기억이 낱말 읽기를 예측하지 못 한다고 하였다. 과제의 유형에 따라 낱말 읽기 및 낱말 쓰기에 대한 설명력이 달라지는 것으로 보인다.

초기 읽기 및 쓰기를 예측하는 철자력 관련 변인 중 하나인 자소 지식은 글자의 이름과 소리에 대한 지식으로 높은 수준일수록 더 발달된 낱말 읽기와 낱말 쓰기 능력을 보인다(Jeong, 2014; Kim, 2009; Kim \& Petscher, 2011; Schatschneider, Fletcher, Francis, Carlson, \& Foorman, 2004). 또한 자소 지식은 자소와 음소의 대응규칙 을 이해하는데 중요하다(Puranik et al., 2011). 또 다른 변인인 복사 기술은 제시된 문자열을 보고 의미를 나타내는 최소문자 단위인 자소의 패턴을 작업기억 속에서 이끌어내어 손글씨로 쓰는 과정이 다(Kandel \& Valdois, 2006). 국내의 아동들은 글자를 학습 혹은 
연습할 때 인쇄물로 제시된 단어나 문장을 보고 베껴 쓰는 복사기 술을 빈번히 사용하고 있다. 복사기술은 낱말 읽기와는 간접적으 로, 낱말 쓰기와는 직접적으로 관련 있는 것으로 나타났다(Kim \& Cho, 2017). 또한 미국의 1학년 아동에게 "The quick brown fox jumps over the lazy dog"를 1 분동안 복사하도록 했을 때, 이러한 문장 복사기술은 철자 쓰기 능력을 $53 \%$ 설명하는 것으로 나타났 다(Kim \& Schatschneider, 2017).

형태의미력이 기초가 되는 형태소인식력, 어휘, 이야기 담화도 초 기 낱말 읽기 및 낱말 쓰기와 관련이 있는 것으로 알려져 왔다. 형태 소인식 능력은 의미를 가진 최소 단위인 형태소에 대해 의식적으로 생각하고, 조작하고, 형태소의 결합으로 이루어진 단어형성의 규칙 을 적용하는 능력이다(Jung, 2014). 여러 개의 형태소로 이루어진 단어 내에서 형태소를 분리하고, 이 형태소에 대한 철자 지식을 바 탕으로 해독 및 의미해석에 활용하는 것이다. 형태소인식 능력은 복합어 혹은 익숙하지 않은 단어를 읽고 이해하는데 필수적이기 때문에 단어 읽기 및 쓰기 능력과 밀접한 관련이 있다(Cho et al., 2008; Jung, 2014; Kim, 2012; Kim \& Jung, 2015; Kim, Kim, \& Cho, 2015).

어휘 능력은 읽기 능력과 상호영향을 주고받는 요인으로, 낱말을 해독할 때 어휘집에 저장된 어휘와 연결하여 낱말을 소리 내어 읽고 의미를 인출해낸다. 유아의 한글 읽기에 대해 살펴본 Jang과 Kim (2003)의 연구에서 어휘력이 낱말 읽기를 글자수-음절 수 대응력과 함께 $36.4 \%$ 설명하는 것으로 나타났다. 또한, 어휘력이 음운인식, 빠 른이름대기, 자소 지식, 자소 쓰기 자동성 등 여러 요인들과 함께 보 았을 때, 낱말 읽기와 낱말 쓰기를 설명할 수 있다고 하였다(Kim et al., 2014; Kim \& Petscher, 2011). 반면에 유치원기부터 초등 2학년까 지의 일반아동을 대상으로 종단연구를 실시한 결과, 어휘력과 담 화능력이 낱말 읽기와 유의한 관계가 있다는 것을 발견하지 못하였 다(Schatschneider et al., 2004). Kim과 Schatschneider (2017)은 담 화 능력과 철자력이 간접적인 관계라고 보고하였다. 이 같이 선행연 구에서는 낱말 수준에서 담화 능력이 읽기와쓰기에 유의한 영향을 미치는지에 대해서 비일관적인 결과들을 보고하고 있다.

선행연구 결과를 종합해보았을 때 알파벳 발달이 활발한 아동 들에게 중요한 요인들은 주로 음운처리, 철자, 형태의미 측면이 있 다. 음운처리 측면에는 음운인식력(phonological awareness), 음운 기억력(phonological memory), 빠른이름대기 능력(rapid automized naming)이 있고, 철자 측면에서 자소지식력(letter knowledge), 복 사기술(copying skill)이 있으며, 형태의미 측면에는 어휘력(vocabulary), 이야기 담화력(narrative discourse), 형태소인식 능력(morphological awareness)이 있다. 따라서 음운처리력, 철자력, 형태의
미력의 3 가지 요인을 8 개의 변인으로 세분화하여 낱말 읽기 및 낱 말 쓰기에 미치는 영향을 다함께 살펴볼 필요가 있다.

초기 낱말 읽기 및 쓰기를 어떤 변인이 예측하는지 살펴본 선행 연구들을 보면 음운처리력, 철자력, 형태의미력을 음운기억, 복사기 술, 형태소인식력까지 포함한 8 가지 변인으로 세분화하여 다 함께 살펴본 연구는 찾아보기 어렵다. 그리고 낱말 읽기와 낱말 쓰기 과 제 시 국내에서는 유치원 아동을 대상으로 주로 의미 낱말을 사용 한 과제를 실시하였으며, 무의미 낱말 과제를 실시한 연구는 찾아 보기 어렵다. 따라서 이런 8 가지 요인들이 초기 문해 능력에 미치는 영향에 대해 알아보기 위해 유치원 7세 반에 재학 중인 아동을 대 상으로, 초기 문해 관련 요인들의 의미 낱말 및 무의미 낱말 읽기와 의미 낱말 및 무의미 낱말 쓰기에 대한 설명력을 살펴보고자 한다.

\section{연구방법}

\section{연구대상}

본 연구의 대상은 강원도, 경기도 지역의 유치원 및 어린이집 7세 반에 재학 중인 아동 총 70 명으로 평균 생활연령은 6 세 3 개월이었 다. 대상 아동들은 한국 비언어 지능검사 제 2판(K-CTONI-2; Park, 2014)의 도형검사에서 지능지수 80 이상으로 평균 100 , 표준편차 9 이다. 또한 낱말 읽기 및 이야기 회상산출 과제 시 조음 오류가 나타 나 발달적으로 조음장애가 의심되는 아동과 검사 시 대화 유지가 되지 않는 아동은 제외하였으며, 담임선생님으로부터 시각, 청각, 신경학적으로 큰 어려움이 없다고 보고된 아동을 대상으로 하였다.

\section{검사도구 및 채점방법}

종속변인

낱말 읽기(word reading)

낱말 읽기 능력을 살펴보기 위해서 강원도난독지원사업에서 사 용한 1학년 평가 항목을 연령에 맞게 수정하였다(Seol, 2018). 자소음소 일치 의미낱말과 무의미낱말 각 7 개로 총 14 개 낱말을 한 번 에 하나씩 제시하여 소리 내어 읽도록 하였다. 제시된 낱말은 종성 없는 낱말 6 개, 종성이 1 개 있는 낱말 4 개, 종성이 2 개 있는 낱말 4 개로 구성되었다. 구성된 자소의 수는 의미낱말에 34 개, 무의미낱 말은 33 개로 구성되어 있어 각 자소별 정반응 1 점, 오반응 0 점을 채 점하여 의미낱말은 34 점, 무의미낱말은 33점으로 계산하였다. 검사 도구의 문항 예시 및 채점 예시는 부록 1 에 제시하였다.

\section{낱말 쓰기(word writing)}

낱말쓰기검사 또한 강원도난독지원사업에서 사용한 1학년 평가 
항목을 연령에 맞게 수정하였다(Seol, 2018). 자소-음소 일치 의미 낱말과 무의미 낱말 각 7 개로 총 14낱말을 들려주고 쓰도록 하였 다. 7 개 낱말은 종성 없는 낱말 3 개, 종성이 1개 있는 낱말 2개, 종성 이 2 개 있는 낱말 2 개로 구성되었다. 구성된 자소의 수는 의미 낱말 에 30 개, 무의미 낱말은 32 개로 구성되어 있어 각 자소별 정반응 1 점, 오반응 0 점을 채점하여 의미 낱말은 30점, 무의미 낱말은 32점 으로 계산하였다. 검사도구의 문항 예시 및 채점 예시는 Appendix 1 에 제시하였다.

\section{독립변인}

음운처리력

아동의 음운처리력을 살펴보기 위해 음운인식, 음운기억, 빠른 이름대기 검사를 실시하였다.

\section{음운인식(phonological awareness)}

음운인식 검사는 한국어 핵심언어 임상평가(K-CELF-5; Pae, Yoon, Seol, \& Jahng, In press) 유치원용의 하위항목을 사용하였다. 과제는 음절 합성, 음절체-종성(body-coda) 합성, 음소 합성 과제 를 사용하였다. 각 과제에서 시범 문항 1 개와 연습문항 1 개를 통해 과제 수행 방법을 익힌 후 본 문항 4 개를 실시하여, 총 12 문항을 수 행하였다. 정반응은 1 점, 오반응은 0 점으로 채점하였다. 검사도구 의 문항 예시 및 채점 예시는 Appendix 1에 제시하였다.

\section{음운기억(phonological memory)}

음운기억 검사는 한국어 읽기검사(KOLRA; Pae, Kim, Yoon \& Jahng, 2015)의 항목을 사용하였다. 과제는 $2,3,4,5$ 음절의 무의미 낱말을 들려주고 따라 말하게 하는 검사로, 음절 수에 따라 5 문항 씩 총 20 문항으로 이루어져 있다. 각 음소 당 정반응 1 점, 오반응 0 점으로 처리하여 총점 189 점을 채점하였다. 검사도구의 문항 예시 및 채점 예시는 Appendix 1에 제시하였다.

\section{빠른이름대기(rapid automized naming)}

빠른이름대기 검사는 한국어 핵심언어 임상평가(K-CELF-5; Pae et al., In press)의 사물 빠른이름대기와 한국어 읽기 검사(KOLRA; Pae et al., 2015)의 숫자 빠른이름대기를 실시하였다. 사물은 '밥, 눈, 달, 꽃, 빗', 숫자는 '1(일), 2(이), 3(삼), 4(사), 5(오)'가 $10 \times 5$ 형태로 무작위로 배열되어 있으며 할 수 있는 한 빨리 이름을 산출 하도록 하여 소요시간의 평균을 점수로 하였다.

\section{철자력}

아동의 철자력을 살펴보기 위해 자소 지식, 복사하기 검사를 실 시하였다.

\section{자소 지식(letter knowledge)}

자소의 이름 지식과 소리 지식을 살펴보기 위해 각각 9 문항 총 18 문항의 검사를 실시하였다. 자소 이름 항목은 자음 6 개, 모음 3 개 로 구성되었으며 자소 소리는 초성 자음 3 개, 모음 3 개, 종성 자음 3 개로 구성되었다. 각 문항별 정반응은 1 점, 오반응은 0 점으로 채점 하여 총 18 점을 계산하였다. 검사도구의 문항 예시 및 채점 예시는 Appendix 1에 제시하였다.

\section{복사기술(copying)}

복사기술 과제는 제시된 문장을 보고 얼마나 정확하게 쓸 수 있 는지 살펴보기 위해 30 초 복사 과제를 실시하였다. 이는 제한 시간 인 30초 내에 최대한 빠르고 정확하게 글자를 쓸 수 있는 만큼 쓰는 과제이다. 연습문항으로 ‘바다’라는 낱말을 제시하고 10초 동안 쓰 도록 하여 과제를 이해하도록 한 후, 본 문항을 실시하였다. 본 문항 을 실시할 때 검사자는 아동에게 "선생님이 이번에는 30 초 동안 문 장을 보여줄 거예요. 선생님이 시작하면 00이가 쓸 수 있는 만큼 문 장을 보고 쓰면 돼요. 선생님이 '그만'이라고 할 때까지 해주세요." 라고 말하였다. 제시한 문장은 “점박이 강아지는 토끼를 보았습니 다”이다. 채점은 자소 정확도 단위로 실시하였다. 검사도구의 문항 예시 및 채점 예시는 Appendix 1에 제시하였다.

\section{형태의미력}

아동의 형태의미 능력을 살펴보기 위해 형태소인식, 어휘, 이야 기문법 회상력 검사를 실시하였다.

\section{형태소인식(morphological awareness)}

아동의 형태소인식 능력을 살펴보기 위해서 초등학생을 대상으 로 한 선행연구의 과제(Jung, 2014)를 기반으로, 본 연구의 대상자 에 적합하도록 재구성하였다. 과제는 두 개의 어근을 합성하거나 접사와 어근을 합성하여 실제 사용 낱말을 만드는 유형 6문항, 실 제 사용되지 않는 낱말을 만드는 유형 6문항으로, 총 12 문항을 실 시하였다. 검사도구의 문항 예시 및 채점 예시는 Appendix 1에 제 시하였다.

어휘(vocabulary)

어휘 능력을 살펴보기 위해서는 한국어 핵심언어 임상평가(K- 
CELF-5; Pae et al., In press) 유치원용의 표현어휘 항목을 사용하였 다. 과제는 3 개의 연습문항, 19 개의 본 문항으로 이루어져 있으며, 그림을 제시한 후 검사자가 질문을 하면 그에 맞는 답을 산출하도 록 되어 있다. 반응에 따라서 2점 혹은 1점으로 채점하여 총 38점을 받을 수 있다. 검사도구의 문항 예시 및 채점 예시는 Appendix 1에 제시하였다.

이야기문법 회상력(story grammar recalling)

아동이 들은 내용과 일치하는 어휘를 떠올려 담화를 구성하고 산출하는 능력을 보기 위해 한국어 이야기 평가(KONA; Kwon, Jin, $\& \mathrm{Pae}, 2016)$ 를 실시하였으며 대상자 연령에 적합한 공.그네 이야기 회상산출을 실시하였다. 아동의 반응을 전사하여 배경, 계기사건, 내적반응, 시도, 결과에 해당하는 이야기문법이 그네이야기에서 10 개, 공이야기에서 9 개로 총 19 개를 산출하였는지 확인하여 이야기 문법 회상률(아동이 산출한 이야기문법 수 $/ 19 \times 100)$ 을산출하였다.

\section{자료의 통계처리}

본 연구는 SPSS 23.0 프로그램을 이용하여 분석하였다. 변인들 의 상관관계를 살펴보기 위해 Pearson 상관분석을 실시하였다. 초 기 문해 관련 요인의 낱말 읽기와 낱말 쓰기 설명 요인을 알아보기 위하여 단계 중다회귀분석(multiple regression analysis)을 실시하 였다. 연구문제에 따라 종속변인은 각각 의미 낱말 읽기 점수, 무의 미 낱말 읽기 점수, 의미 낱말 쓰기 점수, 무의미 낱말 쓰기 점수로 하였고, 독립변수는 빠른이름대기, 음운인식, 음운기억, 이야기구 성력, 형태소인식, 표현어휘, 자소 지식, 복사기술 점수로 하였다. 각 독립변인 간 다중공선성을 확인하기 위해 공차한계와 VIF 지수를 살펴본 결과 모든 변인에 대해 공차한계는 0.1 보다 컸으며, VIF 지 수는 2 미만으로 나타났다.

\section{신뢰도}

검사 실시의 일관성을 높이기 위하여 언어병리를 전공한 박사 1 명에게 전반적인 평가 방법에 대하여 훈련을 받고 실시하였다. 채
점의 신뢰도를 확인하기 위하여 언어병리를 전공하고 있는 대학원 생 1 명과 제 1 연구자가 검사별 $30 \%$ 에 해당하는 자료에 대해 검사자 간 신뢰도를 확인하였다. 그 결과 낱말 읽기의 전사 신뢰도는 $96.5 \%$, 음운기억의 전사 신뢰도는 $97.1 \%$, 이야기문법 회상의 전사 신뢰도 는 $96.5 \%$ 였다. 낱말 읽기, 낱말 쓰기, 음운인식, 음운기억, 빠른이름 대기, 자소 지식, 복사기술, 어휘, 형태소인식의 검사자 간 채점 신뢰 도는 $100 \%$ 였으며, 이야기문법의 채점 신뢰도는 $93.3 \%$ 였다.

\section{연구결과}

\section{변인의 기술통계량 및 변인 간 상관관계}

학령 전 아동의 의미 및 무의미 낱말 읽기, 낱말 쓰기와 변인들의 상관관계는 Table 1에 제시된 바와 같다.

\section{의미 낱말 읽기에 대한 변인들의 설명력}

Table 2에 나타난 바와 같이 학령전기 아동의 의미 낱말 읽기를 설명하는 초기 문해 관련 요인이 무엇인가를 알아보기 위해 중다회 귀분석을 실시한 결과, 자소 지식, 빠른이름대기, 음운기억, 형태소 인식력이 의미 낱말 읽기 수행력을 $57.2 \%$ 설명하는 것으로 나타났다. 각 변인을 자세히 살펴보면, 자소지식이 $39.5 \%(F=44.477, p<.001)$ 설명하여 의미 낱말 읽기 수행력을 설명하는 가장 큰 변인으로 나 타났고, 빠른이름대기가 $11.1 \%(F=15.021 p<.001)$ 더 설명하고, 음 운기억은 $3.6 \%(F=5.256, p<.05)$ 더 설명하며, 형태소인식은 $3.0 \%$ $(F=4.514, p<.05)$ 추가적으로 설명하는 것으로 나타났다. 복사기 술, 음운인식, 표현어휘, 이야기문법 회상력은 의미 낱말 읽기 수행 력을 설명하는 유의한 변인이 아닌 것으로 나타났다.

\section{무의미 낱말 읽기에 대한 변인들의 설명력}

Table 3에 나타난 바와 같이 학령전기 아동의 무의미 낱말 읽기 를 설명하는 초기 문해 관련 요인이 무엇인가를 알아보기 위해 중 다회귀분석을 실시한 결과, 자소 지식, 빠른이름대기, 음운기억, 복 사기술이 무의미낱말 읽기 수행력을 $65.1 \%$ 설명하는 것으로 나타

Table 1. Correlation among the variables related to word reading ability and word writing ability

\begin{tabular}{|c|c|c|c|c|c|c|c|c|}
\hline & RAN & PM & PA & Voca & MA & $\begin{array}{l}\text { Story grammar } \\
\text { recalling }\end{array}$ & $\begin{array}{c}\text { Letter } \\
\text { knowledge }\end{array}$ & Copying \\
\hline Word reading & $-.540 * * *$ & $.455^{* * *}$ & $.464^{* * *}$ & $.307^{* *}$ & $.450 * * *$ & .163 & $.629 * * *$ & $.497^{* * *}$ \\
\hline Nonsense word reading & $-.525^{* * *}$ & $.480^{* * *}$ & $.512^{* * *}$ & $.365^{* *}$ & $.449^{* * *}$ & $.200^{*}$ & $.721^{* * *}$ & $.550^{* * *}$ \\
\hline Word writing & $-.522^{* * *}$ & $.446^{* * *}$ & $.514^{* * *}$ & $.442^{* * *}$ & $.445^{* * *}$ & $.208^{*}$ & $.697^{* * *}$ & $.652^{* * *}$ \\
\hline Nonsense word writing & $-.471^{* * *}$ & $.405^{* * *}$ & $.565^{* * *}$ & $.312^{* *}$ & $.373^{* *}$ & $.230^{*}$ & $.554^{* * *}$ & $.662^{* * *}$ \\
\hline
\end{tabular}

RAN = rapid automized naming; $\mathrm{PM}=$ phonological mMemory; $\mathrm{PA}=$ phonological awareness $\mathrm{Voca}=$ vocabulary; $\mathrm{MA}=$ morphological awareness ${ }^{*} p<.05,{ }^{* *} p<.01,{ }^{* * *} p<.001$ 
Table 2. Multiple regression analysis explaining word reading ability

\begin{tabular}{|c|c|c|c|c|c|c|c|}
\hline Model & Variables & B & SE B & Beta & $t$ & $\mathrm{R}^{2}$ & $\Delta R^{2}$ \\
\hline 1 & LK & 1.433 & 0.215 & 0.629 & $6.669^{* * *}$ & .395 & .395 \\
\hline \multirow[t]{2}{*}{2} & LK & 1.134 & 0.210 & .498 & $5.391^{* * *}$ & .506 & .111 \\
\hline & RAN & -.259 & .067 & -.358 & $-3.876^{* * *}$ & & \\
\hline \multirow[t]{3}{*}{3} & LK & .905 & .227 & .397 & $3.980^{* * *}$ & .543 & .036 \\
\hline & RAN & -.262 & .065 & -.361 & $-4.036^{* * *}$ & & \\
\hline & PM & .239 & .104 & .215 & $2.293^{*}$ & & \\
\hline \multirow[t]{4}{*}{4} & LK & .761 & .231 & .334 & $3.289^{* *}$ & .572 & .030 \\
\hline & RAN & -.248 & .064 & -.342 & $-3.898^{* * *}$ & & \\
\hline & PM & .225 & .102 & .203 & $2.214^{*}$ & & \\
\hline & MA & .782 & .368 & .189 & $2.125^{*}$ & & \\
\hline
\end{tabular}

$\mathrm{LK}=$ letter knowledge; $\mathrm{RAN}=$ rapid automized naming; $\mathrm{PM}=$ phonological memory; $\mathrm{MA}=$ morphological awareness. ${ }^{*} p<.05,{ }^{* *} p<.01,{ }^{* * *} p<.001$.

Table 3. Multiple regression analysis explaining nonsense word reading ability

\begin{tabular}{|c|c|c|c|c|c|c|c|}
\hline Model & Variables & B & SEB & Beta & $t$ & $\mathrm{R}^{2}$ & $\Delta \mathrm{R}^{2}$ \\
\hline 1 & LK & 1.748 & .204 & .721 & $8.569 * * *$ & .519 & .519 \\
\hline \multirow[t]{2}{*}{2} & LK & 1.480 & .202 & .610 & $7.323^{* * *}$ & .598 & .079 \\
\hline & RAN & -.233 & .064 & -.302 & $-3.622^{* *}$ & & \\
\hline \multirow[t]{3}{*}{3} & LK & 1.261 & .218 & .520 & $5.774^{* * *}$ & .627 & .029 \\
\hline & RAN & -.235 & .062 & -.305 & $-3.770 * * *$ & & \\
\hline & PM & .227 & .100 & .192 & $2.268^{*}$ & & \\
\hline \multirow[t]{4}{*}{4} & LK & 1.162 & .218 & .479 & $5.323^{* * *}$ & .651 & .024 \\
\hline & RAN & -.166 & .069 & -.215 & $-2.400^{*}$ & & \\
\hline & PM & .213 & .098 & .181 & $2.182^{*}$ & & \\
\hline & Copying & .257 & .123 & .192 & $2.095^{*}$ & & \\
\hline
\end{tabular}

$\mathrm{LK}=$ letter knowledge; $\mathrm{RAN}=$ rapid automized naming; $\mathrm{PM}=$ phonological memory. ${ }^{*} p<.05,{ }^{* *} p<.01,{ }^{* * *} p<.001$.

Table 4. Multiple regression analysis explaining word writing ability

\begin{tabular}{|c|c|c|c|c|c|c|c|}
\hline Model & Variables & B & SE B & Beta & $t$ & $\mathrm{R}^{2}$ & $\Delta R^{2}$ \\
\hline 1 & LK & 1.565 & .195 & .697 & $8.016^{* * *}$ & .486 & .486 \\
\hline \multirow[t]{2}{*}{2} & LK & 1.158 & .179 & .516 & $6.466^{* * *}$ & .646 & .160 \\
\hline & Copying & .544 & .099 & .439 & $5.506^{* * *}$ & & \\
\hline \multirow[t]{3}{*}{3} & LK & 1.030 & .186 & .459 & $5.536^{* * *}$ & .667 & .021 \\
\hline & Copying & .526 & .097 & .424 & $5.418^{* * *}$ & & \\
\hline & MA & .646 & .317 & .159 & $2.040^{*}$ & & \\
\hline
\end{tabular}

$\mathrm{LK}=$ letter knowledge; $\mathrm{MA}=$ morphological awareness.

${ }^{*} p<.05,{ }^{* *} p<.01,{ }^{* * *} p<.001$.

났다. 각 변인을 자세히 살펴보면, 자소 지식이 $51.9 \%(F=73.431$, $p<.001)$ 설명하여 무의미 낱말 읽기 수행력을 설명하는 가장 큰 변 인으로 나타났고, 빠른이름대기는 $7.9 \%(F=13.116, p<.01)$ 더 설명 하고, 음운기억은 $2.9 \%(F=5.143, p<.05)$ 를 추가적으로, 복사기술 이 $2.4 \%(F=4.388, p<.05)$ 설명하는 것으로 나타났다. 음운인식, 형태소인식, 표현어휘, 이야기문법 회상력은 무의미 낱말 읽기 수행
력을 설명하는 유의한 변인이 아닌 것으로 나타났다.

\section{의미 낱말 쓰기에 대한 변인들의 설명력}

Table 4에 나타난 바와 같이 학령전기 아동의 의미 낱말 쓰기를 설명하는 초기 문해 관련 요인이 무엇인가를 알아보기 위해 중다회 귀분석을 실시한 결과, 자소 지식, 복사기술, 형태소인식력이 의미 
Table 5. Multiple regression analysis explaining nonsense word writing ability

\begin{tabular}{|c|c|c|c|c|c|c|c|}
\hline Model & Variables & B & SE B & Beta & $t$ & $\mathrm{R}^{2}$ & $\Delta \mathrm{R}^{2}$ \\
\hline 1 & Copying & .919 & .126 & .662 & $7.289^{* * *}$ & .439 & .439 \\
\hline \multirow[t]{2}{*}{2} & Copying & .724 & .124 & .521 & $5.857^{* * *}$ & .550 & .111 \\
\hline & PA & 1.593 & .392 & .362 & $4.064^{* * *}$ & & \\
\hline \multirow[t]{3}{*}{3} & Copying & .633 & .124 & .456 & $5.113^{* * *}$ & .591 & .041 \\
\hline & PA & 1.221 & .403 & .277 & $3.028^{* *}$ & & \\
\hline & LK & .599 & .233 & .238 & $2.571^{*}$ & & \\
\hline
\end{tabular}

$\mathrm{PA}=$ phonological awareness; $\mathrm{LK}=$ letter knowledge.

${ }^{*} p<.05,{ }^{* *} p<.01,{ }^{* * *} p<.001$.

낱말 쓰기 수행력을 $66.7 \%$ 설명하는 것으로 나타났다. 각 변인을 자세히 살펴보면, 자소 지식이 $48.6 \%(F=64.255, p<.001)$ 설명하 여 의미 낱말 쓰기 수행력을 설명하는 가장 큰 변인으로 나타났고, 복사기술은 $16.0 \%(F=30.315, p<.001)$ 더 설명하고, 형태소인식력 은 $2.1 \%(F=4.160, p<.05)$ 를 추가적으로 설명하는 것으로 나타났 다. 음운인식, 빠른이름대기, 음운기억, 표현어휘, 이야기문법 회상 력은 의미 낱말 쓰기 수행력을 설명하는 유의한 변인이 아닌 것으 로 나타났다.

\section{무의미 낱말 쓰기에 대한 변인들의 설명력}

Table 5에 나타난 바와 같이 학령전기 아동의 무의미 낱말 쓰기 를 설명하는 초기 문해 관련 요인이 무엇인가를 알아보기 위해 중 다회귀분석을 실시한 결과, 복사기술, 음운인식, 자소 지식이 무의 미 낱말 쓰기 수행력을 59.1\% 설명하는 것으로 나타났다. 각 변인 을 자세히 살펴보면, 복사기술이 $43.9 \%(F=53.127, p<.001)$ 로 무의 미 낱말 쓰기 수행력을 설명하는 가장 큰 변인으로 나타났고, 음운 인식은 $11.1 \%(F=16.513, p<.001)$ 더 설명하고, 자소 지식은 $4.1 \%$ $(F=6.611, p<.05)$ 를 추가적으로 설명하는 것으로 나타났다. 빠른 이름대기, 음운기억, 표현어휘, 형태소인식력, 이야기문법 회상력은 무의미 낱말 쓰기 수행력을 설명하는 유의한 변인이 아닌 것으로 나타났다.

\section{논의 및 결론}

본 연구에서는 유치원 아동의 음운처리력, 철자력, 형태의미력을 세분화하여 각 요인이 낱말 읽기 및 낱말 쓰기에 어떠한 설명력을 갖는지 살펴보았다. 음운처리력 측면에서, 빠른이름대기 능력과 음 운기억력이 의미 유무와 관계없이 낱말 읽기 능력에 설명력을 갖는 다는 결과가 나타났다. 이는 음운 정보를 정확하고 빠르게 처리하 는 아동일수록 낱말 읽기를 더 정확하게 한다는 선행연구 결과를 지지한다(Kim \& Kim, 2009; Park, S. G. et al., 2013; Yang, Kim, \&
Ra, 2017; Cho et al., 2008; Kim \& Petscher, 2011). 본 연구에서는 음 운기억력을 측정하기 위한 도구로 무의미 낱말 따라말하기를 실시 하였다. 무의미 낱말 따라말하기 과제를 포함시킨 음운처리력이 초 기 읽기 발달의 진전에 미치는 영향을 살펴본 Kim과 Kim (2009) 은 음운처리력이 초기 읽기 발달의 진전에 영향을 미친다고 하였 다. 이외에 유치원 아동을 대상으로 한 읽기 및 쓰기 연구에서 무의 미 낱말 따라말하기로 음운기억력을 측정한 연구는 찾아보기 어렵 다. 읽기폭검사, 문장 따라말하기, 숫자 바로 따라말하기, 숫자 거꾸 로 따라말하기 등의 과제로 음운기억력을 측정한 선행연구(Wagner et al., 1997; Kim et al., 2010)에서는 음운기억력이 낱말 읽기에 대해서 예측력을 갖지 않는다고 나타났다. 음운기억력을 측정하는 방법에 따라서 결과가 다르게 나타날 수 있을 것으로 보인다. 빠른 이름대기 능력과 음운기억력이 낱말 읽기에 설명력이 있다고 나타 난 반면 음운인식능력은 낱말 읽기를 제외하고 무의미 낱말 쓰기 만을 설명하는 것으로 나타났다. 본 연구에서 실시한 읽기 및 쓰기 과제는 자소와 음소가 일치하는 낱말로 구성되어 있다. 국내 유치 원 아동들이 자소-음소 일치 낱말을 $97 \%$ 의 정확도로 읽어낼 수 있 다는 Kim과 Pae (2007)의 연구결과를 생각해보았을 때, 본 연구에 서 읽기 및 쓰기 과제를 할 때 음운을 합성, 변별하는 등의 조작 능 력까지는 필요로 하지 않았을 것으로 보인다. 음운인식력이 낱말 읽기에 설명력을 갖는다는 결과를 보고한 선행연구(Cho et al., 2008; Kim \& Petscher, 2011)는 자소와 음소가 불일치하는 낱말도 과제 에 포함했다. 연구대상의 발달 단계와 읽기 및 쓰기 과제의 난이도 에 따라 음운인식력이 갖는 설명력이 다르게 나타날 수 있는 것으 로 보인다. 무의미 낱말 쓰기에 음운인식력이 철자력과 함께 설명력 이 나타난 것은 유아들이 자소 지식을 기반으로 음운인식력을 활 용하여 의미지식 없이, 들려준 말소리에 대응하는 자소를 썼기 때 문인 것으로 볼 수 있다. 이중경로모형에 따르면 낱말 읽기를 할 때 어휘 경로와 비어휘 경로 모두 음운정보의 활성화가 요구된다. 따 라서 본 연구의 결과에서 낱말 읽기에 대해 의미 유무와 관계없이 음운을 처리하는 능력이 높은 관련이 있다고 나타난 것은 이중경 
로모형을 지지한다고 할 수 있다.

철자력 측면에서는 자소 지식이 낱말 읽기 및 낱말 쓰기 능력에 대해 의미유무와는 상관없이 모두 설명력을 갖는 것으로 나타났 다. 이는 자소 지식력이 높은 수준일수록 더 발달된 문해력을 보인 다는 선행연구결과와 일치한다(Jeong, 2014; Kim, 2009; Kim \& Petscher, 2011; Schatschneider et al., 2004). 이러한 결과는 학령전 기 아동들이 낱말을 읽거나 쓸 때 자소의 이름과 소리 지식을 기반 으로 자소와 음소를 대응하는 단계라고 볼 수 있다. 누리과정(Ministry of Health and Welfare, 2019)에서는 만 3세부터 '자신의 생각 을 글자와 비슷한 형태나 글자로 표현한다', '말과 글의 관계에 관심 을 가진다' 등의 읽기 쓰기 관련 목표를 제시하였다. 누리과정 목표 와 본 연구결과를 함께 연결지어 보면, 개정된 누리과정에서 제시 하는 읽기 쓰기 관련 목표는 현실을 반영하여 매우 시기적절하다 고할수 있다.

다음으로, 복사기술은 의미 낱말 읽기를 제외하고 무의미 낱말 읽기와 의미 및 무의미 낱말 쓰기에 대하여 설명력을 갖는 것으로 나타났다. 자소와 음소가 불일치하는 의미 낱말 읽기에 대해서 복 사기술이 간접적으로 영향을 미친다고 한 선행연구(Kim \& Cho, 2017) 결과가 있는데, 본 연구와는 읽기과제 난이도에 차이가 있다. 자소와 음소가 일치하는 의미 낱말을 읽는 것은 이미 유치원 아동 들이 높은 정확률로 할 수 있기 때문에(Kim \& Pae, 2007), 제시된 자소의 패턴을 기억하여 손글씨로 쓰는 복잡한 과정이 필요한 복 사기술까지는 설명력을 갖지 않는 것으로 보인다. 유치원 아동들의 실제 수행력을 넘어선 문장을 복사하는 능력을 봤을 때는 자소를 기반으로 읽어야 하는 무의미 읽기를 설명하는 것으로 보인다. 낱 말 쓰기는 쓰고자 하는 낱말의 음운 표상을 떠올리고 각 음소를 표 기하는 자소를 연결지어 손글씨로 쓰는 능력이 필요한데, 문장을 복사하는 기술 또한 제시된 자소를 패턴에 맞게 손글씨로 쓰는 능 력이 필요하다. 복사하기를 통해 글자를 학습하는 아동들이 앞으 로도 그러한 방법을 통해 쓰기 연습을 한다면 낱말 쓰기에 친숙도 뿐만 아니라 수행력도 높아질 것으로 보인다.

형태의미력 측면에서 살펴보면, 의미를 가진 가장 작은 단위인 형태소를 인식하고 조작하는 능력인 형태소인식 능력이 의미 낱말 읽기 및 쓰기에 대한 설명력을 갖는 것으로 나타났다. 이는 이른 시 기인 만 4세부터 발달하기 시작하는 단어형성의 규칙인 형태소인 식 능력이 초기 읽기 발달 단계에 있는 유치원, 초등 저학년 아동의 낱말 읽기에 영향을 미친다고 한 선행연구(Cho et al., 2008; Kim, 2012; Jung, 2014; Kim \& Jung, 2015; Kim et al., 2015)의 결과와 일 치한다. 이중경로모형의 의미 낱말을 읽을 때 주로 사용되는 어휘 경로에서 의미체계가 사용된다는 것을 생각해보았을 때, 형태소인
식 능력이 의미 낱말에만 설명력이 있는 것은 이중경로모형에 해당 하는 결과라고 할 수 있다. 이를 통해 학령전기의 아동은 의미 낱말 을 읽거나 쓸 때 형태소의 결합으로 이루어진 단어형성의 규칙을 활용하는 것을 알 수 있다. 무의미 낱말 읽기와 쓰기에 대해서는 설 명력을 갖지 않는 것으로 나타났다. 제시한 무의미 낱말은 실제 있 지 않은 낱말로 이루어져 있으므로 의미를 기반으로 하는 형태소 인식력이 설명력을 갖지 않는 것이다.

이야기문법회상력과 어휘력은 낱말 읽기 및 낱말 쓰기에 대한 설 명력이 없는 것으로 나타났다. 담화는 읽기이해와 더욱 직접적으로 연결되기 때문에(Kim, 2017), 본 연구에서 실시한 낱말 수준의 읽 기 및 쓰기 과제에 대해서 이야기문법 회상력의 설명력이 나타나지 않은 것을 알 수 있다. 또한 어휘력을 살펴보기 위해서 한국어 핵심 언어 임상평가(K-CELF-5; Pae et al., In press)의 표현어휘 항목을 살펴보았는데, 후속 연구에서는 다양한 어휘 범주를 포함한 어휘 력을 살펴보아야 할 것이다. 또한 언어발달지연 아동을 대상으로 어휘력의 설명력을 살펴보면 의의가 있을 것이다.

본 연구의 결과를 종합해보면 음운처리력이 의미 유무와 상관없 이 낱말 읽기에 설명력을 갖는 점, 의미에 해당하는 형태소인식력 이 의미 낱말 읽기에만 설명력을 갖는 점 등이 이중경로모형을 지 지하는 것으로 나타났다. 또한, 낱말 읽기와 낱말 쓰기에 대해서 음 운지식, 철자지식 그리고 그에 더하여 형태소인식 능력까지의 설명 력이 모두 $57.2 \%$ 에서 $66.7 \%$ 사이에 속하는 것으로 나타났다. 이는 읽기에 대한 삼각형 모델(triangle model)과 쓰기에 대한 3중 단어 구성이론(triple word-form theory)에서 주장한 낱말 읽기와 낱말 쓰기 발달 관련 요소가 음운지식, 철자지식, 더 나아가 의미 혹은 형 태지식이라는 것을 지지하는 것이다. 그리고 Chall (1996)의 읽기 발 달 단계를 국내 아동들에 대입시켜보면 만 5-6세인 유치원 7세 반의 아동들이 읽기 전 단계와 문자해독 단계에 속한다고 할 수 있었는 데 실제 국내 선행연구 결과와 본 연구 결과를 조합하면 현재 한국 의 유치원 7세반 아동들은 철자지식을 기반으로 자소와 음소의 대 응관계를 알고 소리 내어 읽는 문자해독 단계에 있다고 할 수 있다.

연구 결과를 토대로 다음과 같은 제한점 및 후속 연구를 제언한 다. 본 연구는 유치원 7세 반 아동을 대상으로 실시되었다. 낱말 읽 기 및 낱말 쓰기에 어떤 영향력을 미치는지 살펴보았다. 초기 낱말 읽기 및 낱말 쓰기 능력에 대한 요인들의 설명력을 살펴보려면 더 어린 연령부터 각 능력의 설명력이 어떻게 변화하는지 종단연구를 통해 살펴보는 것이 필요하다. Bahr 등(2012)은 음운처리력, 철자 력, 형태의미력이 상호작용을 함으로써 문해 발달이 이루어지고 있 다고 하였으므로, 국내 아동을 대상으로 3가지 요인이 발달하면서 어떤 관계를 갖는지 살펴보아야 할 것이다. 또한 유치원 단계에서부 
터 발달성 난독아이들을 조기 선별할 수 있는 방법을 마련하는 것 이 필요하다.

\section{REFERENCES}

Bahr, R. H., Silliman, E. R., Berninger, V. W., \& Dow, M. (2012). Linguistic pattern analysis of misspellings of typically developing writers in grades 1-9. Journal of Speech, Language, and Hearing Research, 55(6), 1587-1599.

Berninger, V. W., Abbott, R. D., Jones, J., Wolf, B. J., Gould, L., AndersonYoungstrom, M., \& Apel, K. (2006). Early development of language by hand: composing, reading, listening, and speaking connections; three letter-writing modes; and fast mapping in spelling. Developmental Neuropsychology, 29(1), 61-92.

Berninger, V. W., Abbott, R. D., Nagy, W., \& Carlisle, J. (2010). Growth in phonological, orthographic, and morphological awareness in grades 1 to 6 . Journal of Psycholinguistic Research, 39(2), 141-163.

Chall, J. S. (1996). Stages of reading development (2nd ed.). Fort Worth, TX: Harcourt Brace.

Coltheart, M., Rastle, K., Perry, C., Langdon, R., \& Ziegler, J. (2001). DRC: a dual route cascaded model of visual word recognition and reading aloud. Psychological Review, 108(1), 204-256.

Cho, J. R., McBride-Chang, C., \& Park, S. G. (2008). Phonological awareness and morphological awareness: differential associations to regular and irregular word recognition in early Korean Hangul readers. Reading and Writing, 21(3), 255-274.

Choi, E. Y., \& Lee, J. H. (2010). Analysis of structural equation modelling on relationships among young children's early literacy skills, word reading, and word writing. The Journal of Korea Open Association for Early Childhood Education, 15(5), 405-435.

Ehri, L. C. (2000). Learning to read and learning to spell: two sides of a coin. Topics in Language Disorders, 20(3), 19-49.

Jang, Y. G., \& Kim, S. H. (2003). Relations of young children's Hangeul reading to reading-related skills and home environments. The Korean Journal of Developmental Psychology, 16(3), 87-101.

Jeong, J. (2014). An examination of first graders' consonant-vowel naming, word recognition, and reading fluency. The Journal of Elementary Education, 27(3), 119-136.

Jung, K. H. (2014). Morphological awareness and reading ability of schoolaged children from grades 1 to 3. Communication Sciences \& Disorders, 19(1), 21-30.
Kandel, S., \& Valdois, S. (2006). Syllables as functional units in a copying task. Language and Cognitive Processes, 21(4), 432-452.

Kim, A., Yoo, H., \& Kim, U. (2010). The relationship of phonological awareness, rapid naming, letter knowledge, short-term memory, and working memory to Hangul word recognition abilities. Korean Journal of Special Education, 45(1), 247-267.

Kim, B. H., \& Cho, J. R. (2017). Relations of copying skills with word reading and writing among Korean kindergarten children. The Korean Journal of Developmental Psychology, 30(1), 63-82.

Kim, G. (2012). Relation between literacy and morphological awareness in kindergarten children (Master's thesis). Kyungnam University, Changwon, Korea.

Kim, H. J., \& Kim, D. (2009). The developmental pattern of phonological processing and early reading abilities for preschool children. Proceedings of the 2009 conference the Korean Society of Special Education, 123-147.

Kim, M. B., \& Pae, S. (2007). Word recognition and phonological awareness of kindergartener, second and fourth graders. Journal of Speech-Language \& Hearing Disorder, 16(2), 89-107.

Kim, M., \& Pae, S. (2011). The decoding development of Korean children in word reading. Korean Journal of Communication \& Disorders, 16(2), 143153.

Kim, S. H., \& Jung, K. H. (2015). Morphological awareness and reading abilities for early elementary school students with poor reading skill. Journal of Speech \& Hearing Disorders, 24(2), 35-47.

Kim, S. M., Kim, J. Y., \& Cho, J. R. (2015). Cross-language transfer of morphological awareness and its relations with reading and writing in Korean and English. The Korean Journal of Developmental Psychology, 28(2), 89105.

Kim, Y. S. (2009). The foundation of literacy skills in Korean: the relationship between letter-name knowledge and phonological awareness and their relative contribution to literacy skills. Reading and Writing, 22(8), 907-931.

Kim, Y. S., \& Petscher, Y. (2011). Relations of emergent literacy skill development with conventional literacy skill development in Korean. Reading and Writing, 24(6), 635-656.

Kim, Y. S., Al Otaiba, S., Puranik, C., Folsom, J. S., \& Gruelich, L. (2014). The contributions of vocabulary and letter writing automaticity to word reading and spelling for kindergartners. Reading and writing, 27(2), 237-253.

Kim, Y. S. G. (2017). Why the simple view of reading is not simplistic: unpacking component skills of reading using a direct and indirect effect model of reading (DIER). Scientific Studies of Reading, 21(4), 310-333. 
Kim, Y. S. G., \& Schatschneider, C. (2017). Expanding the developmental models of writing: a direct and indirect effects model of developmental writing (DIEW). Journal of Educational Psychology, 109(1), 35-50.

Kwon, E., Jin, Y. S., \& Pae, S. (2016). Korean narrative assessment. Seoul: Hakjisa. Ministry of Health and Welfare. (2019). 3-5 Nuri curriculum. Seoul: Author.

Pae, S., Kim, M. B., Yoon, H. J., \& Jahng, S. M. (2015). Korean Language based Reading Assessment. Seoul: Hakjisa

Pae, S., Yoon, H. J., Seol, A., \& Jahng, S. M. (in press). Korean version of clinical evaluation of language fundamentals preschool. Seoul: Hakjisa.

Park, E. H., Kim, J. H., \& Park, S. H. (2013). A study of comparison between teacher's expectation level and actual teaching level of children's reading and writing by age. Journal of Early Childhood Education, 17(5), 465-487.

Park, E. H., \& Park, S. Y. (2014). A study on mothers' expectation level and actual teaching level of reading and writing for 3-5 year old children by age. Journal of Educational Studies, 45(3), 167-192.

Park, H. (2014). Korean version of comprehensive test of nonverbal intelligence second edition (K-CTONI-2). Seoul: Mindpress.

Park, S. G., Cho, J. R., \& Yu, Y. M. (2013). A predictor study on the literacy of reading underachievers. Special Education Research, 12(1), 155-180.

Puranik, C. S., Lonigan, C. J., \& Kim, Y. S. (2011). Contributions of emergent literacy skills to name writing, letter writing, and spelling in preschool children. Early Childhood Research Quarterly, 26(4), 465-474.

Schatschneider, C., Fletcher, J. M., Francis, D. J., Carlson, C. D., \& Foorman, B. R. (2004). Kindergarten prediction of reading skills: a longitudinal comparative analysis. Journal of Educational Psychology, 96(2), 265-282.
Seidenberg, M. S. (2005). Connectionist models of word reading. Current Directions in Psychological Science, 14(5), 238-242.

Seol, A. (2018). Assessment and Intervention of Korean children with developmental dyslexia and cooperative teaching. Forum proceedings for supporting at risk of developmental dyslexia, Dec. 6, Hallym University Chuncheon, Gangwon-do.

Song, Y., Shin, G. Y., \& Pae, S. (2016). Decoding and spelling abilities of Korean first and second graders with and without language reading difficulties. Journal of Speech-Language \& Hearing Disorders, 25(4), 97-107.

Shin, G. Y. (2017). The development of spelling for children with/without spelling difficulties (Doctoral dissertation). Hallym University, Chuncheon, Korea.

Wagner, R. K., Torgesen, J. K., Rashotte, C. A., Hecht, S. A., Barker, T. A., Burgess, S. R., ... \& Garon, T. (1997). Changing relations between phonological processing abilities and word-level reading as children develop from beginning to skilled readers: a 5-year longitudinal study. Developmental Psychology, 33(3), 468-479.

Yang, M. (2009). Spelling development of kindergarten students: a one year longitudinal study. Communication Sciences \& Disorders, 14(1), 14-33.

Yang, M., Kim, B., Ra, J., (2017). Predicting word reading and spelling in first graders with dyslexia. Communication Sciences \& Disorders, 22(4), 690704.

Yoon, H. J., Kim, M., \& Pae, S. (2011). The decoding skills of school-aged children with poor reading skills. Korean Journal of Communication \& Disorders, 16(4), 582-596. 
Appendix 1. 검사도구 문항 예시 및 채점 예시

낱말 읽기 및 쓰기

\begin{tabular}{lccc}
\hline 과제유형 & 문항 & 아동 반응 & 점수 \\
\hline 낱말 읽기 & & & 4 \\
자소-음소 일치 의미 낱말 & 조개 & 조개 & 2 \\
자소-음소 일치 무의미 낱말 & 수젤 & 수 & \\
낱말 쓰기 & & & 0 \\
자소-음소 일치 의미낱말 & 필통 & "몰라요" & 3 \\
자소-음소 일치 무의미 낱말 & 우타 & 우타 & \\
\hline
\end{tabular}

음운기억

\begin{tabular}{lccc}
\hline 과제유형 & 들려준 내용 & 아동 반응 & 점수 \\
\hline 2음절 & 망씁 & 망씁 & 6 \\
3음절 & 발무린 & 발무리 & 7 \\
4음절 & 솔포코절 & 소폴코전 & 8 \\
5음절 & 범민차호관 & 범민사호간 & 11 \\
\hline
\end{tabular}

음운인식

\begin{tabular}{|c|c|c|c|c|}
\hline 과제유형 & 들려준 내용 & 목표 반응 & 아동 반응 & 점수 \\
\hline 낱말 합성 & "/새/와 /털/을 더하면 무슨 소리가 되지요?" & 새털 & 털 & 0 \\
\hline 음절 합성 & "사/와 /탕/을 더하면 무슨 소리가 되지요?" & 사탕 & 사탕 & 1 \\
\hline 음절체 종성 합성 & "/사/와 / ㄴ/을 더하면 무슨 소리가 되지요?" & 산 & 무응답 & 0 \\
\hline 음소 합성 & "/피와 / $\perp /$ 를 더하면 무슨 소리가 되지요?" & 포 & “몰라요" & 0 \\
\hline
\end{tabular}

형태소인식

\begin{tabular}{|c|c|c|c|c|}
\hline 과제유형 & 들려준 내용 & 목표 반응 & 아동 반응 & 점수 \\
\hline \multirow{2}{*}{ 실제 사용 낱말 } & 유리로 만든 컵을 유리컵이라고 합니다. 종이로 만든 컵은 무엇이라고 할까요? & 종이컵 & 종이컵 & 1 \\
\hline & $\begin{array}{l}\text { 난지 얼마 되지 않은 고추를 햇고추라고 합니다. 난지 얼마 되지 않은 감자는 무엇이라고 } \\
\text { 할까요? }\end{array}$ & 햇감자 & $\begin{array}{l}\text { 난지 얼마 되지 } \\
\text { 않은 감자 }\end{array}$ & 0 \\
\hline \multirow[t]{2}{*}{ 실제 비사용 낱말 } & 장미가 피를 흘리면 장미피라고 합니다. 가방이 피를 흘리면 무엇이라고 할까요? & 가방피 & 가방 & 0 \\
\hline & 음식을 잘 먹는 사람을 음식쟁이라고 합니다. 줄넘기를 잘 하는 사람을 무엇이라고 할까요? & 줄넘기쟁이 & 줄넘기쟁이 & 1 \\
\hline
\end{tabular}

어휘

\begin{tabular}{|c|c|c|c|c|}
\hline 질문 & 2점 반응 & 1점 반응 & 아동 반응 & 점수 \\
\hline 여자 아이가 뭐하고 있나요? & 타다, 자전거를 타다 & & 자전거 타고 있어요 & 2 \\
\hline 이 사람들을 뭐라고 하나요? & 관중, 청중 & 듣는 사람 & 듣는 사람들 & 1 \\
\hline 이건 뭐예요? & 체중계 & 저울 & 시계 & 0 \\
\hline
\end{tabular}


Sangeun Won, et al. • Predicting Word Reading and Word Writing of Kindergarteners

COMMUNICATION SCIENCES\& DISORDERS

자소 지식

\begin{tabular}{|c|c|c|c|c|}
\hline 과제유형 & 질문 & 목표 반응 & 아동이 가리킨 반응 & 점수 \\
\hline 자소 이름 & $\begin{array}{l}\text { ‘지읒(ㅈ)'이 어디 있지요? } \\
\text { ‘아(ㅏ)'가 어디 있지요? }\end{array}$ & $\begin{array}{l}x \\
r\end{array}$ & $\begin{array}{l}x \\
0\end{array}$ & $\begin{array}{l}1 \\
0\end{array}$ \\
\hline 자소 소리 & $\begin{array}{l}\text { /ㅁ/(받침) 소리가 나는 글자는 어디에 있나요? } \\
\text { /사/ 소리가 나는 글자는 어디에 있나요? } \\
\text { /ㅅ/ 소리가 나는 글자는 어디에 있나요? }\end{array}$ & $\begin{array}{l}\text { ㅁ } \\
\text { 나 } \\
\text { 人 }\end{array}$ & $\begin{array}{l}\circ \\
\text { 나 } \\
\wedge\end{array}$ & $\begin{array}{l}0 \\
1 \\
1\end{array}$ \\
\hline
\end{tabular}

복사기술

\begin{tabular}{lccc}
\hline 제시한 문장 & 아동 & 아동 반응 & 자소 점수 \\
\hline 점박이 강아지는 토끼를 보았습니다. & 1 & 점박이 강아지는 & 16 \\
& 2 & 점박이 ᄀ & 8 \\
\hline
\end{tabular}




\section{국문초록}

\section{취학전 아동의 낱말 읽기 및 낱말 쓰기 설명요인: 음운처리력, 철자력, 형태의미력을 중심으로 원상은 $\cdot$ 원효은 2 장우정 2 이정민 2 배소영 3 \\ '한림대학교 보건과학대학원 언어병리학과, ${ }^{2}$ 한림대학교 일반대학원 언어병리청각학과, ${ }^{3}$ 한림대학교 언어청각학부}

배경 및 목적: 국내 유치원시기 아동은 초기 문해 발달이 활발하게 이루어지고 있다. 이 연구는 취학전 아동을 대상으로 낱말 읽기 및 낱말 쓰기 능력에 대해 음운처리력, 철자력, 형태의미력이 어떤 설명력을 갖는지 살펴보았다. 방법: 지능 평균이 100 인 7 세 반 아동 70 명 을 대상으로 자소와 음소가 일치하는 2음절 낱말 14 개와 무의미 낱말 14 개를 읽고 쓰도록 한 후, 자소 기준으로 채점하였다. 초기 문해 력 설명 변인으로 음운처리력에서는 음운인식, 빠른이름대기, 음운기억, 철자력에서는 자소 지식, 복사기술, 그리고 형태의미력에서는 형태소인식, 어휘, 이야기문법 회상을 측정하고 중다회귀분석을 실시하였다. 결과: 의미 낱말 읽기는 자소 지식, 빠른이름대기, 음운기 억, 형태소인식력이 $57.2 \%$, 무의미 낱말읽기는 자소 지식, 빠른이름대기, 음운기억, 복사기술이 $65.1 \%$ 설명하였다. 의미 낱말 쓰기는 자 소 지식, 복사기술, 형태소인식력이 66.7\%를, 무의미 낱말 쓰기는 복사기술, 음운인식, 자소 지식이 $59.1 \%$ 설명하였다. 논의 및 결론: 낱 말 및 무의미 낱말 읽기에 있어 빠른이름대기와 음운기억력이, 무의미 쓰기에 있어 음운인식력이 설명력을 갖는 것은 음운처리력이 초 기 문해력과 깊은 관련이 있음을 지지한다. 철자력이 높은 설명력을 갖는 것은 한국의 취학전 아동들이 자소와 음소의 대응관계를 활 발하게 탐색하고 습득해가는 음성음운 단계에 있음을 시사한다. 또한 의미를 기반으로 하는 형태소인식력이 의미 낱말 읽기와 쓰기에 설명력이 있고, 음운처리력이 의미 낱말 및 무의미 낱말 읽기 모두에 설명력을 갖는 것은 이중경로모형이 한국아동에게도 적용됨을 시 사한다. 후속연구를 통해 유치원 단계에서부터 발달성 난독아이들을 지원할 수 있는 방법을 마련할 필요가 있다.

핵심어: 유치원기 낱말 읽기와 쓰기, 음운처리력, 자소 지식과 복사기술, 형태소인식력

\section{참고문헌}

권유진, 진연선, 배소영(2016). 한국어 이야기 평가. 서울: 학지사

김기예(2012). 유치원 아동의 형태소인식 능력과 문식성 간의 관계. 경남대학교 대학원 석사학위논문.

김미배, 배소영(2007). 유치원, 초등 2 ·4학년의 낱말재인 및 음운인식 능력. 언어치료연구, 16(2), 89-107.

김미배, 배소영(2011). 낱말읽기에서의 초등학생 음운해독력 발달. 언어청각장애연구, 16(2), 143-153.

김봉희, 조증열(2017). 유치원 아동들의 복사 기술과 단어 읽기 및 단어 쓰기와의 관계. 한국심리학회지: 발달, 30(1), 63-82.

김상미, 김지연, 조증열(2015). 형태소인식의 한국어와 영어 간 전이와 읽기 쓰기와의 관계. 한국심리학회지: 발달, 28(2), 89-105.

김순호, 정경희(2015). 초등 저학년 읽기학습부진아동의 형태소인식과 읽기능력. 언어치료연구, 24(2),35-47.

김애화, 유현실, 김의정(2010). 음운인식, 빠른 자동 이름대기, 자모지식, 단기기억, 작동기억과 한글 단어인지 능력 간의 관련성에 관한 연구: 읽기장애

조기선별을 위한 기초연구. 특수교육학연구, 45(1),247-267.

김희진, 김동일(2009). 읽기 학습장애 위험아동 조기선별을 위한 음운처리과정과 초기읽기의 발달패턴 분석. 한국특수교육학회 추계학술대회, 123-

147.

박은혜, 김정효, 박선혜(2013). 유아 연령별 읽기, 쓰기에 대한 교사의 기대수준과 실제 지도수준 비교. 유아교육학논집, 17(5), 465-487.

박순길, 조증열, 유영미(2013). 읽기부진아동의 문식성 예언변인 연구. 특수교육, 12(1), 155-180.

박은혜, 박신영(2014). 만 3-5세 유아의 연령별 읽기와쓰기에 대한 어머니의 기대수준과 실제 지도수준. 교육과학연구, 45(3), 167-192.

박혜원(2014). 한국 비언어 지능검사-제2판(Korean Comprehensive Test of Nonverbal Intelligence-Second Edition, K-CTONI-2). 서울; 마인드프 레스.

보건복지부(2019). 3-5세 누리과정 고시. 서울: 대한민국 보건복지부. 
배소영, 김미배, 윤효진, 장승민(2015). 한국어읽기검사. 서울: 학지사.

배소영, 윤효진, 설아영, 장승민(출판예정). 한국어 핵심언어 임상평가 유치원판. 서울: 학지사.

설아영(2018). 난독학생 평가와 중재 및 협력수업 사례. 강원도 난독학생 지원 포럼 자료집.

송 엽, 신가영, 배소영(2016). 초등학교 1,2 학년 언어. 읽기부진아동과 정상아동의 해독 및 철자 특성. 언어치료연구, 25(4), 97-107.

신가영(2017). 철자 쓰기 부진 아동과 일반 아동의 철자쓰기 발달 특성. 한림대학교 대학원 박사학위논문.

양민화(2009). 유치원 아동의 철자발달 단기종단연구. Communication Sciences \& Disorders, 14(1), 14-33.

양민화, 김보배, 나종민(2017). 초등학교 1학년 난독증 아동의 단어읽기 및 철자능력 예측지표 연구. Communication Sciences \& Disorders, 22(4),

690-704.

윤효진, 김미배, 배소영(2011). 읽기부진아동의 해독특성. 언어청각장애연구, 16(4), 582-596.

장유경, 김숙현(2003). 유아의 한글 읽기에 영향을 미치는 요인. 한국심리학회지: 발달, 16(3), 87-101.

정경희(2014). 1-3학년 학령기 아동의 형태소인식과 읽기능력. Communication Sciences \& Disorders, 19(1), 21-30.

정종성(2014). 초등학교 입학 아동의 자모 인식, 단어 해독, 읽기 유창성 수행 수준 탐색. 초등교육연구, 27(3), 119-136.

최은영, 이지현(2010). 유아의 초기 문해기술과 단어읽기, 단어쓰기의 관계에 대한 구조모형 분석. 열린유아교육연구, 15(5), 405-435.

\section{ORCID}

원상은(제1저자, 대학원생 https://orcid.org/0000-0003-1719-4502); 원효은(공동저자, 대학원생 https://orcid.org/0000-0001-5782-3452); 장우정(공동저자, 대학원생 https://orcid.org/0000-0001-8023-2263); 이정민(공동저자, 대학원생 https://orcid.org/0000-0002-3870-5650); 배소영(교신저자, 교수 https://orcid.org/0000-0001-6577-0880) 